Александра Весић* Филолошки факултет Универзитет у Београду Докторанткиња
371.3::811.134.2'243

https://doi.org/10.18485/zivjez.2020.40.1.14 Оригинални научни рад

\title{
АЛЕКСАНДАР СОЛЖЕЊИЦИН - БЕСЕДА НА ХАРВАРДУ
}

Овај рад кроз призму говора на Универзитету Харвард 1978. године, проучава стилистику беседе руског писца Александра Солжењицина. У свом говору Солжењицин размишљајући о прошлости и садашњости Русије, користи реторичке универзалије: метафору, епитет, поређење; реторичке узвике, анафору, више везника, синтаксички паралелизам. Осим стилске анализе самог текста и анализе самог говора, предмет овог истраживања ће бити и битне компоненте беседништва, беседничка тријада logos, ethos, pathos, као и реторичке универзалије у говорништву Солжењицина. Тропи и фигуре се описују са тачке гледишта повећања утицаја на примаоца. Закључак је такав да је овладавање визуелним и изражајним средствима језика показатељ високог нивоа комуникацијске компетенције говорника.

Кључне речи: стилистика, Солжењицин, реторика, стилске фигуре, беседа, беседник, аудиторијум.

\section{1. Увод}

Реторика је процветала у Русији одмах после реформе судства. Плевако ${ }^{1}$ и Карабчевски ${ }^{2}$ су тако направили читаву школу реторике. Беседе су се писале, училе напамет

* vsaska94@gmail.com

1 Плевако Фјодор Никифорович (1842-1909), руски адвокат и правник, судски беседник, активни грађански саветник.

2 Карабчевски Николај Платонович (1851-1925), један од најпознатијих адвоката и судских беседника дореволуционарне Русије. Од 1913. је био председник савета адвоката Санкт Петербурга. 
и говориле. Прве руске говорнике је мало ко видео али је њихова имена знала цела Русија. Следећу етапу су обележили наступи депутата у Државној думи (Скупштини). Она је Русији открила многа имена. То је било време парламентаризма. Време говорника. На тај начин се припремала и Фебруарска револуција, за време које су људи први пут почели да разговарају и дискутују не само у затвореном простору, већ са живим народом и гомилама окупљеним на јавном отвореном простору.

Уметност говорништва пред масом је постала посебно популарна за време Октобарске револуције. Истина, најуспешнији говори су се завршавали убиством тих истих популарних говорника и због тога су и добијали на посебној тежини и значају. Због тога је говорништво Троцког било мало успешније него беседе Керенског. Са појавом Стаљина руско говорништво је нестало, као што је и било „природно“ да нестане. Иако је Стаљин држао говоре, и иако су ти говори били кратки и једноставни, морао је да их учи напамет. Он их је градио као непроменљиве заповести. Фраза „Свет ће бити сачуван и учвршћен ако народи света узму ствар очувања света у своје руке“ је била општеприсутна.

Едвард Радзински, познати драматург и писац, открива да тема нашег рада није само говорник или само писац, већ комплексни спој оба: „Александар Исаевич је говорник, када почиње да говори о моралу. Али је и писац. А то је веома тешко. Мисао изречена је лаж. Темељ рада писца је: ћути, скривај се и таји“. Добар говорнички наступ подразумева синхронизовање три основна елемента - беседника, беседе и слушалаца (Аврамовић 2008: 173).

\section{2. Беседник, беседа, аудиторијум}

Александар Исаевич Солжењицин, руски писац, драматург, есејиста-публициста, песник, друштвени и политички активиста, живео је и радио у СССР-у, Швајцарској, Америци и Русији. Члан је Руске и Српске академије наука и уметности 
и добитник Нобелове награде. Стварао је у време када су друштвени и политички живот државе о којој је писао били потпуно испреплетани и друштвени ангажман је захтевао одређену политичку обојеност, те је тако 1945 . године због писама у којима је критиковао Стаљина, ухапшен, осуђен и послат у сибирски логор. У логорима је провео скоро девет година, а након тога му је одузето држављанство, па је 1974. године емигрирао. Најпре је живео у Швајцарској, затим у САД-у у Вермонту, да би се 1990-их вратио у Русију, где је дочекан као идеолог руске нације. Прославио се делима „Један дан Ивана Денисовича“ и „Архипелаг Гулаг“, а у књижевност је увео тему Стаљинових логора, оставши јој веран у највећем делу опуса.

Како у иностранству, тако и у домовини, Солжењицин је етикетиран као славенофил, националиста и антисемита (Струве 2005). Вероватно се због тога и није одазивао на најразличитије позиве за гостовања по Америци. Ипак је пре четрдесет две године овај руски и совјетски писац, нобеловац и дисидент по први пут у свом избеглиштву решио да јавно наступи. Харвард му је доделио почасни докторат из књижевности, те је Солжењицин прихватио позив да говори на свечаности 8. јуна 1978. године. Интерни договор Универзитета Харвард је био да име говорника сваке године буде чувано у тајности како се не би нагађало о тематици говора и политичкој обојености одлуке позивања госта. Иако су припреме биле тајне, како наводе тадашњи медији, свечана дворана Харварда је могла да прими око тридесет хиљада људи, а тада је била пуна. Александру Солжењицину је то био највећи аудиторијум пред којим је наступао, а говор који је припремио трајао је скоро сат времена. О значају догађаја говори чињеница да је говор преносила јавна телевизија, као и многобројне новинске агенције. Говор је одржао на свом матерњем, руском језику, а пратио га је симултани превод на енглески.

До тог тренутка је важио за најславнијег и најпоштованијег аутора са руског говорног подручја, за човека, скоро пророка, 
који је био симбол не само Русије, већ целе епохе руских грађанских ратова, логора, репресија, егзила. Говор је завршио уз стојећи аплауз, мада се међу стручњацима воде расправе да ли је тај аплауз био само израз куртоазије младе и образоване публике или нешто више, јер су се његова дела након тога ретко спомињала, а ако су се и спомињала, то је било у негативној конотацији. Окарактерисан је као славенофил који је незахвално оцрнио земљу која га је оберучке прихватила... Беседник се обраћа не само разуму него и осећању и машти слушалаца уз помоћ елемената као што су логичност, знање, убедљивост и песничко уздизање беседног материјала (Аврамовић 2008: 61). Солжењицин свесно биранајразличитије теме о којима говори јер је свестан да стоји пред младим, а још важније образованим аудиторијумом. Ти млади људи су они који ће убудуће обликовати светско и јавно мњење. „Прикладном усменом речју може утицати на мисао, осећање, вољу и радњу других људи“ (Животић и Станојевић 2013: 15). А доказ томе је чињеница да је издат (и преведен на неколико језика) читав том различитих критика, што различитих медија, што филозофа. Кажу да је говор осуђен на успех или пропаст у зависности од талента самог говорника и његовог наступа. Солжењицину ово није био први пут да наступа пред публиком - тренирао је своје реторске способности пред политичарима и у државним установама Совјетског Савеза. Усправног држања, чврстог става, непоколебљиве мисли и продорног погледа водио је свој говор путем који је замислио. Уз јасну дикцију и гестикулацију која је пратила кулминације његових говора, био је беседник кога је тешко заборавити.

\subsection{0 беседи и беседниковом аудиторијуму}

Велики број тврдњи, које је тада изнео Солжењицин, не само да нису постале неактуелне, већ су сазреле и добиле ново и дубље значење у XXI веку. Он говори о политици, култури, науци, медијима али и универзалним и вечитим питањима: слободе, вере, наде... Као што је филозоф Шпенглер 
критиковао Запад и прогнозирао његову пропаст, тако и Солжењицин дијагностикује кључна подручја слабости западне цивилизације. Обратићемо пажњу на стилске фигуре којима се Солжењицин користио док је као дисидент изрицао осуду Запада пред судијама, поротом и публиком западне цивилизације:

1) губитак храбрости: „Губитак храбрости је можда оно најуочљивије што радознали посматрач може да примети на данашњем Западу. Западни свет је изгубио грађанску храброст, и у целини и у свакој земљи појединачно, свакој влади, свакој партији, и - наравно - Уједињеним нацијама. Овај губитак храбрости посебно је видљив код владајућих група и интелектуалне елите, и ствара утисак губитка храбрости у читавом друштву. Да вас подсетим, губитак храбрости се, одувек, сматрао почетком краја."

2) агресивност: „Овај губитак храбрости, негде до потпуног одсуства мушкости, праћен је повременим изливима беса и нетолерантности већине тих бирократа, против слабих влада и земаља које нико не подржава, или оних који не могу да пруже никакав отпор. Међутим језик заостаје и онемогућава отпор моћним владама, агресивним претњама силом и међународном тероризму.“

3) похлепа: „Сваки грађанин је добио слободу коју је желео и материјална добра, у толикој количини и таквог квалитета, да то гарантује остварење среће - схваћене у површном смислу који је створен током тих деценија. (Међутим, у овом процесу се превиђа један психолошки детаљ: стална жеља за што више ствари и још бољим животом, и борба да се то оствари, утиснути су на лицима многих западњака, који изгледају забринуто, чак депресивно, мада таква осећања сакривају.“

4) неморал (злоупотреба закона): „Правне норме и људска права (веома широко) одређује систем закона. Правно беспрекорне нафтне компаније, откуп проналазака нових врста енергије, да се не би користиле. Потпуно легални отровни производи, који угрожавају безбедност: јавности је остављена слобода да их не купује." 
5) угрожавање људских права: „Одбрана индивидуалних права доведена је до екстрема, тако даје, беззаштите, друштво немоћно да се супротстави одређеним појединцима. (аплауз) Дошло је време да се на Западу више не штите толико људска права, него да се припази на њихове обавезе. (аплауз) Насупрот томе, отворено је најшире поље деструктивној и неодговорној слободи деловања. Изгледа да је друштво недовољно заштићено од дубоке моралне декаденције, злоупотребе људске слободе за насиље над младима, порнографским, криминалним и 'хорор' филмовима. (аплауз)“

6) критика јавности и правних оквира: „Правни поредак не може да их одбрани од корозивног деловања зла. Правни оквир - посебно у Сједињеним Америчким Државама довољно је широк да подстакне не само индивидуалне слободе, него и извесне злочине. Када власт започне озбиљну борбу против тероризма, јавност је одмах оптужује за кршење грађанских права преступника. Иако су на Западу створени најбољи социјални услови, необично је да у њему још увек постоји криминал и да је присутан у далеко већој мери него у сиромашном и обесправљеном совјетском друштву. (Од оних који су тамо названи криминалцима, а налазе се у логорима, велики број - чак велика већина - нису преступници, и они се, против безакоња државе, нису бранили правним средствима).“

7) условљеност трендовима: „На Западу се, без икакве цензуре, издвајају мисли које су у тренду од оних које су застареле; ништа није забрањено, и коначно, иако их нико не забрањује, оне реално не могу да нађу пут до периодичне штампе, књига и факултетских катедри. (аплауз) Правно, ваши истраживачи су слободни, али су условљени садашњим модним трендовима."

8) слаб карактер: „Непобитна чињеница, која се не може оспорити, је слабљење људског карактера на Западу и његово јачање на Истоку. Наши људи, за 60 година, и народи Источне Европе, за 30 године, прошли су кроз духовну обуку која их је издигла далеко изнад западног искуства. Тежак живот и стална претња смрћу, обликовала је дубље и занимљивије карактере него, просперитетни и строго регулисан, живот на Западу.“ 
9) морални пад друштва: „Према томе, наше друштво ако би требало да се промени по узору на ваше, то би подразумевало уздизање, али и срозавање - које би много коштало. Људска душа, која деценијама пати због насиља,жуди за нечим вишим, топлијим и чистијим, од онога што нам данас нуди западно масовно друштво, чије је обележје терор одвратним рекламама, безумном телевизијом и неподношљивом музиком. (аплауз) Понекад, постоје и директна, готово опипљива, упозорења: центар ваше демократије и културе на неколико сати је остао без струје и убрзо су - гомиле америчких грађана појуриле да пљачкају и силују. Против светске, промишљене стратегије комунизма, Западу могу помоћи само морална правила - ништа друго (аплауз)..."

10) психолошка слабост и нестабилност: „Али ни највеће, ни најмоћније оружје неће помоћи Западу, док не превазиђе немоћ своје воље. У стању такве психолошке слабости, ово оружје дефетистима постаје највеће оптерећење. За одбрану је нужно и умрети, али на то није спремно друштво које негује култ земаљског благостања. (аплауз)“

11) учауреност и заосталост у развоју: „Западно мишљење је постало конзервативно: само се одржава стање у свету, какво јесте, да се ништа не би променило. Опуштајући сан status quo-a је обележје друштва које је окончало свој развој. Запад је само напредовао и напредовао, у складу са својим прокламованим циљем, под руку са сјајним техничким Прогресом. И одједном се појавио у стању садашње немоћи.“

12) материјализам: „Сам по себи, заокрет од Ренесансе је очигледно био историјски неизбежан: Средњи век се исцрпео, постао је неподношљиво деспотско сузбијање телесног човека у корист духовног.Међутим, истовремено-несразмерно, претерано - одбацили смо дух у корист материје. Што је човечанство, у свом развоју, све више материјалистичко, тим пре даје повод за претпоставку да нам следује - социјализам, а затим комунизам."

Професор Сима Аврамовић (2008) је дефинисао тројаку сврху беседништва: да поучи, да пружи ужитак и да увери (дефинисана је и као способност убеђивања, као речитост, сводила се на елоквентност говорника чија је намера да, 
побуђујући дух и емоције, делује преко срца на разум) реторика утиче на прихватање мисли, али и емоцијама подстиче на радњу и понашање. Он додаје да су ови циљеви остварљиви ако говорник поседује знање (образованост), ако износи само истину (етичност) и ако, примењујући принципе беседне технике, улаже све своје умне и емотивне способности искрено верујући у оно што говори (таленат). Беседа на Харварду је свакако имала за циљ да поучи и увери публику у то да је свет подељен на сопствену штету и да западна цивилизација има велики удео у томе. Не можемо се сложити да пружа ужитак, али свакако је беседник успео да пробуди емоције које ће подстаћи аудиторијум на делање.

Поред вечитог трагања за одговором на питања шта говорити и како говорити, још је већи проблем стварало питање етоса онога ко говори (Карнеги 2013). Уверљивост се постиже чврстим карактером, када је говор такав да беседника чини достојним поверења, јер ми уопште најрадије и најспремније поклањамо поверење честитим људима, нарочито онда када је реч о стварима које нису јасне и у које се може сумњати (Аврамовић 2008: 64).

Ако по реакцији публике можемо видети да је поверовала у ставове и аргументе беседника, требало би поставити питање: Зашто су прве реакције на Солжењицинов говор биле критике у медијима? Зато што су ти исти медији пратили и објављивали његове говоре и радове, те се ово могло узети као директан атак и израз незахвалности Руса кога је Америка оберучке прихватила у азил и избеглиштво. Мада никада не би требало сметнути са ума питање - колико је и да ли је тешко прихватити најбољу руску интелигенцију, академике, нобеловце и докторе наука?

\section{3. Структура беседе и стилистика текста}

Свака беседа се састоји из две основне компоненте: логичке и естетске, односно садржине и форме или, још јасније, од онога „шта се говори“ и онога „како се говори“. У разним 
временима, с обзиром на разноврсне околности, предност се често давала једној или другој компоненти (Аврамовић 2008: 209). Међутим, ова беседа је другачија. Онај ко говори је довео публику, а задржало ју је оно што се говорило. У Харвардској беседи Солжењицина се не може раздвојити оно што се говори од онога ко говори и како говори. Јака личност, реторски поткована, писац, нобеловац и беседничка громада Русије. Када говор пише особа чврстог става, особа која је имала храбрости да у културном центру запада, брани исток и указује на његове мане, тешко је анализирати по деловима говор који функционише као целина.

У Солжењициновој беседи нема класичног увода и припреме публике, затим кулминације у разради и поентирања у закључку. Он нас кроз сваки пасус уздиже и води до малих врхунаца и малих закључака, а потом нас одмори на општим местима, као да смо дошли да поразговарамо са пријатељем о политици уз шољу чаја. И баш због тих малих закључака, публика га често поздравља аплаузом.

Тог дана Солжењицин је имао публику која је већином била кохерентна - свршени студенти Харвардског универзитета, истог образовања, истих година. Публика која ће обликовати будућност и мењати садашњост Америке. Модерни уџбеници саветују да се наклоност најлакше стиче уколико се говор започне причом или речима које ће директно погодити слушаоце и лично их везати за тему (Аврамовић 2008: 250), што Солжењицин и чини коришћењем личних заменица, директном обраћању аудиторијуму и говором из првог лица: „Девиза вашег универзитета је - 'Veritas'. Неки од вас то већ знају, док ће други то сазнати током живота, да истина у тренутку нестане, чим ослаби снага нашег мишљења - мада имамо илузију, да је и даље следимо.“ Од почетка је водио рачуна да његов говор води логика али и емоција. Жонглирао је степеном емотивности, стилом и нивоом излагања, те тако свој говор започиње речима хвале и честиткама дипломцима: „Задовољство ми је да поздравим 327. генерацију свршених студената најстаријег Универзитета Харвард и честитам свим 
дипломцима!“ и одмах након придобијања публике ствара неутрално тло за не тако пријатан говор који следи: „Истина је ретко кад пријатна и готово је увек горка. Ову горчину није могуће избећи ни у овом данашњем излагању - али ја ћу је излити не као непријатељ, већ као пријатељ. Пре три године, у Сједињеним Америчким Државама, исто сам тако говорио - о ономе што се одбацује као неприхватљиво - а са чиме се данас многи слажу." Иако је употребом речи из свакодневног говора постигао утисак непосредности и стварности, ни у једном тренутку није потценио своју публику. Никада није сметнуо с ума да је „лако упропастити садржински сјајан говор, који ће уз то изговорити сасвим солидан беседник, уколико се беседа не прилагоди 'примаоцима поруке', публици, на основу претходне анализе аудиторијума. Говор није монолог, него дијалог, додуше са већим бројем саговорника." (Аврамовић 2008: 308).

Живо и сликовито изражавање доприноси пуном ефекту који говор треба да изазове, јер је упућен не само разуму, него и емоцијама и машти слушалаца. Због тога се у говору, чешће но у писаном тексту, користи фигуративно изражавање које везује пажњу (Нушић 2009). Познато је да се Солжењицин дуго припремао за овај говор, те је самим тим јасно да је промислио дужину текста којим ће изразити своје мисли и начин на који ће организовати текст. Његов израз карактера се препознаје по избалансираном реторичком фокусу и стилским фигурама, чија је функција да аудиторијум прихвати његове идеје. Реторске фигуре су украси, који чине да „говор постане необичан и оригиналан“, што опет има велики значај за усвајање садржине и информације које нуди“ (Аврамовић 2008: 275). Фигуре којима се Солжењицин служи у свом говору су: поређење, епитет, градација, анафора, реторичко питање, антитеза, персонификација, иронија, метафора, метонимија, синегдоха... (Тартаља 2008: 109).

Већ у првим констатацијама које Солжењицин износи срећу се различите стилске фигуре: реторско питање - „Да ли појам „трећег света“, самим тим, значи да постоје три света?“ или: 
- $\quad$ Али ако је цела Америка доживела потпуни пораз, од једне половине једне мале комунистичке земље, шта онда Запад може да очекује у будућности?

- А плач - чују ли га садашњи ватрени пацифисти? Или они то радије не желе чути?

- Па, ко би се сада одрекао свега тога, зашто, због чега онда ризиковати свој живот у одбрани заједничког добра, а посебно мутним ситуацијама, када националну безбедност треба заштитити у некој далекој земљи?

- Па ипак: на основу ког изборног закона је изабрана и коме је одговорна?

- На комунистичком Истоку, новинар има статус државног службеника, али ко је, онда, у западној државној власти тај који је дао овлашћења њиховим новинарима и на који рок?

„Каква је одговорност новинара или новина према својим читаоцима, или историји? Ако су информације нетачне и закључци погрешни, па наведу јавно мњење, или владу, у погрешном правцу, чак допринесу погрешним државним потезима - да ли је било случајева јавног покајања тих новинара, односно тих новина?" - на ова реторичка питања и дилеме Солжењицин даје одговор: „Не, јер би то смањило тираж. Морају се обезбедити, неопходне, конкретне и веродостојне информације, које ће онда порећи и оповргнути оно што се никада не оспорава, а што преовлађује у масовној свести. Колико брзоплетих, немарних, површних, и застрањујућих гледишта свакодневно узнемирава читаоце - и блокира им мозак. (аплауз) Штампа има могућност да обмањује јавно мњење да га изопачи. Створена је ситуација да се терористи славе као хероји, чак да се откривају тајне везане за одбрану земље и бесрамно прегура по приватном животу познатих, под геслом: 'Свако има право да зна све'. (аплауз) Лажна парола, лажног века: много већа него што је изгубљено право људи на незнање, како не би изгубили своју божанску душу - у трачевима, испразним причама, у бесмислицама. (аплауз). Неограничена слобода постоји за штампу, али не и за читаоце. (аплауз)” 
Говорник говором изражава своје мисли, ставове, убеђења, осећања, жеље (исповедна страна), али то чини свесно да би утицао на мисли, емоције и понашање саговорника. Емоционална страна говора инспирисана је садржајем, из њега произилази (Животић и Станојевић 2013: 14). Солжењицин вишекратно користи реторичке узвике, анакенозу и екфонезу, како би утицао на емоције саговорника:

- Како је могуће да је, до недавно, сразмерно мали новоевропски свет свуда тако лако заузимао колоније, и не само да није очекивао озбиљнији отпор, него се обично с презиром односио према могућности било какве перспективе тих народа!

- Понекад, постоје и директна, готово опипљива, упозорења: центар ваше демократије и културе на неколико сати је остао без струје и - убрзо с - гомиле америчких грађана појуриле да пљачкају и силују. То je дебљина филмске траке! Таква је слабост друштвеног поретка и његовог унутрашњег здравља.

- Следећи рат - не нужно нуклеарни, не верујем у то - коначно ће покопати западну цивилизацију. $И$ пред лицем те опасности - с таквим историјским вредностима иза себе, на том нивоу остварене слободе, као и оданошћу према њој - да толико изгуби вољу да се брани!?

- Нису случајна сва вербална комунистичка заклињања - човеку са великим Ч и његовој земаљској срећи. Наводно је то поређење ружно - о блискости у размишљању и начину живота садашњег Запада и садашњег Истока!

- Дакле, током протеклих векова, а у последњих неколико деценија, посебно, када у глобалној равнотежи моћи, тај процес је ескалирао: либерализам, неизбежно слабљен радикализмом, био је принуђен да се повлачи пред социјализмом, а социјализам није брана против комунизма. То је зато што комунистички режим на Истоку одолева и учвршћује се, јер га ватрено 
подржава (осећајући блискост са њим!) - дословно маса интелектуалаца, која не види зло у њему, и само када је то немогуће не видети - правда га.

У говору о прихватању различитости без насиља, уводи се једна од најчешћих стилских фигура коју Солжењицин у овом говору користи - персонификација:

- Душевни немир разбијеног света оживео је и теорије о приближавању водећих западних земаља и Совјетског Савеза - умирујуће замисли која превиђа чињеницу да се ти светови не развијају уједначено, па један не може да се претвори у други без употребе насиља.

Поред персонификованог „немира“, и у овој, као и у многим реченицама срећу се епитети, које говорник обилато користи како би дочарао свој став и резигнираност: душевни немир, разбијен свет, водеће западне земље, умирујуће замисли...

Када се обраћа разуму (логосу) публике, акценат ставља на сопствену личност и карактер (етос):

- $\quad$ Пошто четири године принудно боравим овде и како је преда мном западна публика - мислим да има смисла фокусирати се и на неке карактеристике модерног Запада, онако како ја то видим.

Осим стилским фигурама, комбиновањем логичковербалног садржаја, етичких момената и естетско-емотивног набоја Солжењицин представља аудиторијуму кључне проблеме њиховог друштва:

- Легализам, на одређеном нивоу, изазива парализу: он није у стању да види ни обим, ни смисао дешавања. (персонификација: легализам изазива парализу, није у стању да види обим и смисао дешавања)

- Тако,подмаскомограничењакојепостављадемократија, тријумфује осредњост. (персонификација: демократија поставља ограничења, осредњост тријумфује)

- Све ово теоретски спада у домен слободе и они то не препознају као опозицију њиховој одмереној младалачкој слободи. Дакле, правни поредак не може да их одбрани од корозивног деловања зла. 
(персонификација: правни поредак не може да одбрани друштво; епитети: одмерена младалачка слобода, правни поредак, корозивно деловање)

- Хуманистичка свест се прогласила нашим вођом, не признајућиунутрашњезлоучовеку,нитииједан људски задатак који је изнад земаљске среће, и поставила је у темељ модерне западне цивилизације опасну склоност да се обожавају човек и његове материјалне потребе. (персонификација: хуманистичка свест се прогласила вођом; епитети: хуманистичка свест, наш вођа, унутрашње зло, људски задатак, земаљска срећа, модерна западна цивилизација, опасна склоност, материјалне потребе)

- Независност појединаца од многих облика државног притиска, обезбедила је већини људи удобност какву њихови очеви и дедови нису могли ни да сањају. (контраст, поређење: појединац и облици државног притиска)

- Чак и биологија зна да навика, екстремна сигурност и благостање, није од користи живом бићу. Благостање, у животу западног друштва, данас полако открива своју разорену маску. (персонификација: биологија зна, благостање открива своју разорену маску; епитети: екстремна сигурност, живо биће, западно друштво, разорена маска)

- Тако је остављен простор злу, које данас, са свих страна, отворено удара. (персонификација: зло удара)

- Грешке које смо у почетку превидели, сада нам се свете! (персонификација: грешке се свете)

- $\quad$ Пут који смо прешли, од Ренесансе до данас, обогатио је наше искуство, али смо изгубили Целину, оно Највише, за које смо некада веровали да обуздава наше страсти и неодговорност. (персонификација: пут је обогатио искуство)

- Ево шта је криза: није страшно то што је свет подељен, него што су његови главни делови оболели од сличне 
болести. (персонификација: делови су оболели од

болести; епитети: главни делови, слична болест)

Индиректно укључивање аудиторијума постиже честим постављањем реторичких питања. Реторичким питањима беседник буди патос, који у реторици даје одговор на питање како се говори (Станојевић и Аврамовић 2005). Разум није увек довољан да би се неко убедио у нешто. Понекад је неопходно пробудити емоције.

- Људска душа, која деценијама пати због насиља, жуди за нечим вишим, топлијим и чистијим, од онога што нам данас нуди западно масовно друштво, чије је обележје терор одвратним рекламама, безумном телевизијом и неподношљивом музиком. (аплауз) (персонификација: људска душа пати због насиља, жуди за нечим вишим; епитети: људска душа, нешто више топлије чистије, западно масовно друштво, одвратне рекламе, безумна телевизија, неподношљива музика)

Људи много више ствари просуђују под утицајем мржње, љубави, пожуде, гнева, туге, радости, наде, страха, заблуде или неког другог осећања, него под утицајем истине или правних прописа, правила понашања или законских одредби. Оно што се говори подразумева логичко-аргументациону заснованост говора, ко говори обухвата одређена лична својства говорника, док како се говори циља на излагање које је сугестивно, уверљиво и осећајно (Аврамовић 2008: 62). У његовој беседи се меша етос и патос, логос је свеприсутан и у корелацији је са његовим карактером и емоцијама. Солжењицин је имао природан дар за сугестиван наступ. Додатан патос се испољава убедљивошћу која се јавља због субјективног односа према предмету беседе. Никад не треба сметнути с ума да је сваки говор у ствари дијалог, чак и онда када друга страна - аудиторијум не говори (Аврамовић 2008: 275). Зато ћемо навести примере где је публика својим реакцијама комуницирала са беседником. Солжењицин је немало пута добијао аплаузе и не само аплаузе, већ и овације у току свог говора: 
- Цео свој живот сам провео под комунистичким режимом и могу вам рећи: друштво без чврстог правног оквира је ужасно. Али друштво у коме нема других мерила, осим правних, није достојно човека (овације).

- Ако је, као што тврди хуманизам, човек рођен само за то да буде срећан, он не би био рођен и за смрт. Али, пошто је телесно осуђен на смрт, његов задатак на земљи је, очигледно, духовни: не само за хлеб свакидашњи, јер то није најбољи начин да стекне богатство, а затим живи радосно, него да има трајну и мучну обавезу, тако да целокупан начин живота постане доживљај, пре свега, морална висина (аплауз): да напусти живот као биће узвишеније од оног које је био на почетку. Неминовно, треба изменити систем темељних људских вредности, јер чуди колико је садашњи погрешан. Не може се оцена председникових активности сводити на то колика је наша зарада и да ли је продаја бензина ограничена. (аплауз)

- $\quad$ Ако већ није дошао до свог краја, свет се данас налази на историјској прекретници, која је по значају једнака прелазу из Средњег века у Ренесансу - и захтева од нас духовно просветљење, виши ниво опажања, нови квалитет живота, у коме наша телесна природа неће - као у Средњем веку - бити проклета, али, што је још важније, ни наше духовно биће неће бити погажено као у модерно доба. (аплауз)

- Овај раст је сличан уздизању на виши антрополошки ниво. И никоме на свету није преостао други излаз, него да иде - до највиших висина. (овације)

- Одбрана индивидуалних права доведена је до екстрема, тако да је, без заштите, друштво немоћно да се супротстави одређеним појединцима. (аплауз)

- Дошло је време да се на Западу више не штите толико људска права, него да се припази на њихове обавезе. (аплауз) 
- За одбрану је нужно и умрети, али на то није спремно друштво које негује култ земаљског благостања. (аплауз)

- Изгледа да је друштво недовољно заштићено од дубоке моралне декаденције, злоупотребе људске слободе за насиље над младима, порнографским, криминалним и „хорор“ филмовима. (аплауз)

- Надам се да нико од присутних није помислио да сам ову своју критику западног система спровео због тога да бих уместо њега понудио идеју социјализма. (аплауз)

Иако свој говор назива критиком, свака његова примедба је логички утемељена. Он сам објашњава и даје аргументацију (активација логоса) зашто идеја социјализма није добра: „Не, искуство земаља реалног социјализма, у сваком случају, не нуди социјалистичку алтернативу. Сваки облик социјализма, сам по себи и у свим својим нијансама, доводи до потпуног уништења људског духа и изједначава људски род у смрти.“ Управо то се показује у следећем примеру:

- Ваше друштво не могу да препоручим као узор за преображај нашег. Због богатог душевног развоја наше земље - кроз страдања - у овом веку, савремени западни систем, у његовој садашњем стању духовне исцрпљености, не може да буде привлачан. Тачније, поменута карактеристика вашег начина живота доводи до екстремних патњи.

Солжењицин подразумева политичку освешћеност публике и рачуна на то да су упознати са логички заснованим чињеницама, стога може и да води дијалог са њима (темељ његове беседе је упућен разуму и знању публике - аудиторијум мора бити упознат са Старим Тргом, кубанском експедицијом у Африку...)

- 0, када би знали, како се вашим политичким мудрацима смејала већина младих чиновника Старог Трга. (аплауз)

- Таква су, на пример, била смешна предвиђања неких америчких експерата, да ће се Совјетски Савез 
наћи у Вијетнаму, или Анголи, или да је арогантну кубанску експедицију у Африци најбоље зауставити додворавањем Сједињених Држава Куби. (аплауз)

Иако је Солжењицин промислио начин на који саопштава своје поруке, патос, односно начин на који беседник саопштава неку поруку, није изостављен:

- Против светске, промишљене стратегије комунизма, Западу могу помоћи само морална правила - ништа друго. (аплауз)

- „Потребни су нам слобода и једнакост у веома уском значењу." У складу са тим, говорник упозорава: „Заштита права личности је доведена до такве крајности, да друштво остаје без заштите (аплауз)... од разних личности, тако да је на Западу дошло време да се штите не само права људи, већ и њихове обавезе. (аплауз)“

Борба за права без спомињања фундаменталних обавеза, доводи до тога да ће „друштво остати незаштићено од провалије људске грешности, на примердоћи ће дозлоупотребе слободе у сврху моралног насиља над омладином, као што су порнографија, преступништво или хулиганско понашање“. Солжењицин је у другим говорима причао о „слободи“ која допушта да читав град буде облепљен непријатним рекламама, о „слободи“ џабалебароша даживе на рачун друштва, о „слободи“ државе да руши сувереност других међународних субјеката, уместо да се позабави сопственом економијом. Помињао је он на десетине врста тих „слобода“. Моменат када се схвата зашто је Солжењицинова критика конструктивна је моменат када се доказује да он није неко ко је дошао из просвећење средине о којој проповеда као о безгрешном и савршеном друштву, моменат када се схвати да је у сваку целину свог говора уткао поређења (уједно и критику) Запада и Истока. Не постоји добра и лоша страна, добро и лоше уређење, друштво или цивилизација. Све има мане и предности али обраћајући се аудиторијуму западне цивилизације, првенствено се окреће слабостима њиховог система: 
- Како каже протојереј Андреј Ткачов: „И Запад и црвени Исток су били повезани, јер су и једни и други били хуманисти.“ Једино што су први заступали идеју приватног власништва, а други су били против. Једни су били за умерени разврат у оквиру закона, а други - или за разврат без ограничења, или за строги, али безбожни аскетизам. Свет је био подељен, а обе полутке су боловале од исте болести. И сада смо пожњели, шта само посејали. Ми немамо будућност, ако продужимо да живимо у парадигми овоземаљског задовољства.

- Нису случајна сва вербална комунистичка заклињања - човеку са великим Ч и његовој земаљској срећи. Наводно је то поређење ружно - о блискости у размишљању и начину живота садашњег Запада и садашњег Истока! - али таква је логика развоја материјализма.

Извор неисцељених болести западне цивилизације, он види у погрешној хуманистичкој претпоставци да је „човек, газда овога света, који у себи нема зла, већ сви пороци произилазе из погрешних друштвених система, који треба да буду исправљени“. „Чудно је да, иако су на Западу створени најбољи материјални услови за живот, тамо бележимо вишу стопу криминалитета, него што је то случај са Совјетским Савезом, у којем царују сиромаштво и безакоње."

Процес мишљења на Западу је бинаран - плус или минус, добро или лоше. Али поред тога, има још и горе и боље. Одговоре треба тражити, а не бирати. Солжењицин говори да Запад више није на челу човечанства. И као доказ тога видљиви су одређени симптоми. На пример, „пропаст уметности или одсуство великих државника“ (Кузмич 2018). Публика реагује: „Када је цео живот прожет правом - ствара се атмосфера духовне осредњости, која паралише најплеменитије људске импулсе. (аплауз)“ Подсетио их је да „у $\mathrm{XX}$ веку западне демократије нису самостално победиле ни $\mathrm{y}$ једном великом војном сукобу, већ су се сваки пут ограђивале од противника уз помоћ свог континенталног савезника, чије 
вредности нису прихватале." На Западу се, без икакве цензуре, издвајају мисли које су у тренду од оних које су застареле; ништа није забрањено, и коначно, иако их нико не забрањује, оне реално не могу да нађу пут до периодичне штампе, књига и факултетских катедри. (аплауз)“ Писац је одговарао, да социјализам као модел, ни у којем случају, не предлаже и не пропагира. Али да и западни модел не би предложио свом народу. Ствар је у потрази за правим путем, а не у одабиру између већ постојећих, то је суштина.

Природно је да уз фигуре поређења иде контраст и као закључак поређења стилска фигура која може послужити као одговор на два супротстављена става/мишљења (ЈелачићСрбуљ 2001). Код Солжењицина су то иронија, метафора, градација:

- $\quad$ Готово сви признају да Запад целом свету указује на пут успешног економског развоја, мада га - истина - у последње време подрива хаотична инфлација. (контраст: Запад целом свету указује - преко поређења долази се до контраста између онога како је на Западу и како је у остатку света и ко диктира поредак)

- Међутим, многи који живе на Западу, незадовољни су својим друштвом, презиру га или оптужују да више није на нивоу до кога се уздигао људски род. (градација: незадовољни су, презиру га, оптужују га - од унутрашњег до вербалног исказивања незадовољства)

- $\mathrm{y}$ данашњем западном друштву успостављена је неравнотежа између слободе да се чини добро и слободе да се чини зло. (контраст: слобода да се чини добро и слобода да се чини зло)

- Основни разлог за то је, очигледно, рођен из хуманистичке идеје да у човеку, господару овог света, не постоји унутрашње зло, него да је оно производ само погрешних друштвених система, који се зато морају поправити. (иронија, у овом контексту: човек је господар овог света) 
- Овде је, у сваком случају, најважније да се не прекорачи правни оквир, без икакве стварне моралне одговорности за извртање, за размере прикривања. (истинита чињеница помешана са иронијом: у сваком случају је најважније да се не прекорачи правни оквир)

- Силе светског зла су у коначној офанзиви и ломе нас - а ваши екрани и публикације су пуни неизбежног смеха и погледа кроз ружичасте наочаре. (метафора: поглед кроз ружичасте наочаре)

- Амерички интелектуални слој је изгубио живце и последица тога је много већа претња самим Сједињеним Државама. (метафора: интелектуални слој је изгубио живце)

- На пример, квази тумачења савремене светске ситуације - која делују као окамењени оклопи око глава, кроз који не пробија глас људи из 17 земаља Источне Европе и Источне Азије, не могу да уклоне последице неизбежних догађаја. (метафора: квази тумачења делују као окамењени оклопи око глава)

Сваки говор је једна врста позоришта, а закључак је финале представе: ту и емоције и разум досежу климакс. Успех беседе, зависи од онога „шта се говори“, али и од тога „како се говори“. На ово друго, наравно, утиче избор теме, добар распоред грађе, начин казивања и гестикулације (Аврамовић 2008: 261), а Солжењицин је комбинацијом свих ових фактора успео да остави снажан утисак својим једночасовним говором.

\section{4. Закључак}

Ова контроверзна беседа на Харварду је и даље жива тема научника и стручњака који се баве Солжењицином. Лавине критика које је проузроковала су биле мотив за настанак неколико десетина томова вишејезичних расправа. Иако је већина мишљења да је прекомерно хваљени писац после говора на Харварду постао огорчени, незахвални, неуравнотежени старац, сматрамо да је без обзира на исход умешности којом 
је указано на слабе тачке Запада много већа и има много већу тежину и допринос науци и истраживањима, него биполарна осећања западне публике према самом писцу. Аплауз није био само израз поштовања, он је на крају говора на стенографском запису био забележен не као аплауз, већ као овације! А то означава да је публика не само сагласна, већ и да је разумела и да се слаже са изреченим.

Указивањем на тачке спајања, уз признавање тачака раздвајања, говорник може да остави добар утисак и бар донекле одобровољи несклону публику, што Солжењицин и чини:

Први корак је увођење у тему, ограђивањем од детаљније анализе и неутралне теме као што су хуманистичке науке: „Обим и циљеви овог говора не дозвољавају ми да разматрам на који начин ове особине западног друштва утичу на важне аспекте живота једне нације, као што је основно школовање и високо образовање у хуманистичким наукама и уметности.“

Други корак је директна осуда и критика публике: „Према томе, наше друштво ако би требало да се промени по узору на ваше, то би подразумевало уздизање, али и срозавање - које би много коштало.“

Трећи корак је поновно придобијање публике увођењем разлика и критиковањем сопственог источњачког друштва: „Јесте, не може се друштво оставити у таквом амбису безакоња, као што ми радимо, али је бесмислено и даље остати на терену бездушне правне лакоће, како је то код вас."

Каква год осећања да овај говор буди, јасан је таленат беседника јер је успео да пробуди било какву емоцију код „хладнокрвног, интелигентног и ослоњеног на разум“ Запада. Не заборавимо да су се списи Солжењицина преносили у западним медијима, аудиторијум је био заинтересован за преносе и преводе његових беседа. А по свим делима која су настала на основу ове беседе, несумњиво је да је на основу његових речи имало шта да се преиспита.

Промишљањем логичке повезаности делова беседе на Харварду и коришћењем компаративног метода, долазимо до 
закључка да овај сложени говор почива на добро промишљеној структури и да између свих његових делова влада логичка повезаност (Крик 2011). Укључујући реакцију публике у саму анализу говора, открива се повезаност публике са беседником и градацијски однос публике према примерима које беседник користи. „Апологета царизма“ и „мрзитељ Запада“ је без трунке треме успео да новој генерацији политичара, младих људи који ће водити тај исти Запад „отвори очи“ и укаже на оно што може бити боље и на то да цео подељени свет „болује од истих болести“. Како каже Волтер - „ухо је пут до срца“, а млади Запад је умео да слуша.

\section{ЛИТЕРАТУРА}

Аврамовић 2008: С.Аврамовић, Rhetorike techne вештина беседништва и јавни наступ. Београд: Службени гласник.

Животић и Станојевић 2013: Р. Животић, Д. Станојевић, Реторика и политика. Београд: Јасен.

Јелачић-Србуљ 2001: В. Јелачић-Србуљ, Реторика и Progymnasmata - уџбеник за IV разред филолошких и класичних гимназија. Београд: Филолошка гимназија.

Карнеги 2013: Д. Карнеги, Јавни наступ. Београд: Admiral books. Крик 2011: N. Crick, Rhetorical Public Speaking. Louisiana: Pearson. Кузмич 2018: П. Кузмич, Солжењицин прије и послије „расколничког“ говора на Харварду. Online, [https://www.autograf.hr/solzenjicinprije-i-poslije-raskolnickog-govora-na-harvardu]

Нушић 2009: Б. Нушић, Реторика наука о беседништву. Београд: Чигоја штампа.

Станојевић и Аврамовић 2005: О. Станојевић, С. Аврамовић, Основе реторике и беседништва. Београд: Завод за уџбенике.

Струве 2005: Н. Струве, Явление Солженицына. Попытка синтеза. Online, [http://www.solzhenitsyn.ru/upload/text/Struve_N.A._ YAvlenie_Solzhenitsyna._Popytka_sinteza.pdf]

Тартаља 2008: И. Тартаља, Теорија књижевности. Београд: Завод за уџбенике. 


\section{Александра Весич}

\section{АЛЕКСАНДР СОЛЖЕНИЦЫН - БЕСЕДА НА ГАРВАРДЕ}

\section{Резюме}

В данной работе рассматривается стилистика выступления русского писателя Александра Солженицына в Гарвардском универзитете в 1978 году. Цель работы - с помощью определенных методов, как анализ и синтез, доказательство и опровержение, сделать вывод о том, как и в какой степени хорошо построенная реч, включающая логос, этос и пафос, может произвести впечатление на аудиторию. Раскрывая структуру частей выступления, учитывая его смысл и логические связы, можно сделать вывод, что речь Солженицына была замечена, благодаря объединяющему эффекту триады (выступление, оратор, аудитория).

Ключевые слова: стилистика, Солженицын, риторика, стилистические фигуры, слово, лексика, аудитория. 